\title{
PKM Pelatihan Desain Grafis berbasis Vektor bagi Mahasiswa Universitas Nurul Jadid Probolinggo
}

\author{
Eko Purnomo, ${ }^{1}$ Abdul Hafid ${ }^{2}$, A Dimas Alil Mafacir ${ }^{3}$, Abdulllah ${ }^{4}$, \\ Abdullah ${ }^{5}$, Muhammad Miftahul Ulum ${ }^{6}$, Abdul Wafi ${ }^{7}$, \\ Abdul Hak Mutawakil ${ }^{8}$, Rifqi Alfian Zuhri ${ }^{9}$
}

Universitas Nurul Jadid ${ }^{123456789}$

Submission: 21/07/2021 Received: 14/09/2021 Published: 31/12/2021

\begin{abstract}
Keywords:
Graphic design,

Vector image,

Training,

Inkscape

Abstract.. The development of graphic design has been trusted for a work of technological art that has an important role for various digital industries. Graphic design is a form of visual communication that uses images to convey information or messages as effectively as possible. Graphic design is needed to promote or deliver a product, service, lecture material, and report by companies or educational institutions. This vector-based graphic design training workshop was an appropriate thing for participants to study or deepen their knowledge in the field of graphic design. By having the provision of graphic design skills, students could present information or products effectively, even became a provider of design services or simply be able to choose the best images, so that information could be presented effectively. Training and mentoring of graphic design for participants to understand faster than independent study, accompanied by a module that could serve as a guide even after the training is over. The use of graphic design applications based on open source (inkscape) could produce the best work as well as other design applications.
\end{abstract}

Katakunci:

Desain Grafis, pelatihan, Gambar Vektor, Inkscape

\begin{abstract}
Abstrak. Perkembangan desain grafis telah dipercaya untuk sebuah karya seni rupa teknologi yang memiliki peran penting untuk beragam industri digital. Desain grafis merupakan suatu bentuk komunikasi visual yang menggunakan gambar untuk menyampaikan informasi atau pesan seefektif mungkin. Desain grafis sangat dibutuhkan untuk mempromosikan atau menyampaikan suatu produk, layanan, materi perkuliahan, dan laporan oleh perusahaan ataupun instansi pendidikan. Workshop pelatihan desain grafis berbasis vector ini suatu hal yang tepat guna bagi peserta untuk mempelajari atau memperdalam keilmuan di bidang desain grafis. Dengan memiliki bekal keterampilan desain grafis mahasiswa dapat menyajikan informasi ataupun produk secara efektif, bahkan menjadi penyediakan jasa desain ataupun hanya sekedar mampu memilih gambar yang terbaik sehingga informasikan dapat disajikan dengan efektif. Pelatihan dan pemdampingan desain grafik peserta lebih cepat memahami dibandingkan dengan belajar mandiri, disertai modul yang dapat menjadi panduan meski pelaihan telah usai. Penggunaan aplikasi desain grafis berbasis open source (inkscape) dapat menghasilkan karya terbaik seperti halnya aplikasi desain lainnya.
\end{abstract}




\section{Pendahuluan}

Saat ini, perkembangan desain grafis telah dipercaya untuk sebuah karya seni rupa teknologi yang memiliki peran penting untuk beragam industri digital(Piliang, 2019). Desain grafis merupakan suatu bentuk komunikasi visual yang menggunakan gambar untuk menyampaikan informasi atau pesan seefektif mungkin. Desain grafis sangat dibutuhkan untuk mempromosikan atau menyampaikan suatu produk, layanan, materi perkuliahan, dan laporan oleh perusahaan ataupun instansi pendidikan(Iswandi, 2018). Hasil dari desain grafis dapat diimplementasikan berupa melaui media cetak seperti (flayer, banner, poster, dan lain sebagainya) ataupun secara digital atau emedia. Pemanfaatan grafis dalam menyampaikan pesan di era digital bukan suatu hal yang baru lagi, hal ini dapat selaras dengan jumlah pengguna smartphone masyarakat indonesai yang setiap tahun mengalami peningkatan.

Dari jumlah pengguna smarthone yang terus meningkat Indonesia dapat menjadi pengguna terbersar ke empat didunia. Hal ini dibuktikan pengguna smartphone tahun 2021 mencapai 89\% atau 167 juta jiwa(Zubaedah Hanum, 2021), dan 200 juta jiwa pengguna internet(Riyanto, 2021). Sehingga dapat diartikan media penyampaian informasi ataupun promosi melaui media digital lebih flexible dan efektif yang disampaikan melalui media social atupun website di bandingkan dengan media cetak(Pramesti \& Irwansyah, 2021).

Dalam desain grafis, terdapat istilah gambar raster atau bitmap dan vector. Gambar vector adalah objek yang dibuat dari garis-garis curva yang muncul akibat perhitungan matematika atau algoritma yang berisikan deskripsi panjang, lebar, posisi, arah letak garis dan sebagainya(Adji, 2016). Sedangkan gambar raster atau bitmap merupakan sekumpulan gambar pixcel/point koordinat. Kedua jenis gambar ini sama sama dapat digunakan untuk menyampaikan informasi kepada subjek secara efektif namun ada kelebihan dan kekurangan dari masing masing jenis ini. Gambar vector memiliki kelebihan dari segi kualitas gambar. Gambar vektor tidak akan buram meskipun diperbesar karena dibalik gambar terdapat sekumpulan kode yang memunculkan objek. Karena susunan algoritmiknya, vektor dapat diukur secara tak terbatas dan tetap halus dan tajam bahkan ketika dicetak pada dimensi besar. Sedangkan gambar raster atau bitmap memiliki kelebihan yaitu mendukung keindahan dengan perpaduan warna dan resolusi 
yang tinggi dengan diimbangi dengan kemampuan kartu grafik computer yang seimbang.(Antonius \& Sama, 2020)

Workshop pelatihan desain grafis berbasis vector ini suatu hal yang tepat guna bagi peserta untuk mempelajari atau memperdalam keilmuan di bidang desain grafis. Dengan mempelajari ilmu desain secara mendalam, diharapkan para peserta bisa dan dapat meningkatkan kreativitas dan kualitas karya serta menambah wawasan tentang desain grafis khususnya berbasis vector sebagai bekal untuk menunjang pengetahuan dan keterampilan mereka di dunia industri maupun pendidikan terkait desan grafis. Dengan memiliki bekal keterampilan desain grafis diharapkan mahasiswa dapat menyajikan informasi ataupun produk secara efektif, bahkan menjadi penyediakan jasa desain ataupun hanya sekedar mampu memilih gambar yang terbaik sehingga informasikan dapat disajikan dengan efektif.

Pada program pengabdian ini yang ditujukan kepada mahasiswa umum maupun mahasiswa dari Universitas Nurul Jadid akan dibekali tentang perbedaan gambar vektor, bitmap, teknik dasar desain, teknik pemilihan warna dan keseimbangan perpaduannya, teknik penyimpanan dalam berbagai tipe file, teknik editing atau bagaimana cara memanfaakan gambar yang sudah jadi secara instan pada media internet ataupun dari sumber lain, serta bagaimana agar desain yang dihasilkan sesuai dengan target komunikasi atau pesan dapat tersapaikan dengan efektif.

Aplikasi yang digunakan dalam pelatihan desain grafik pada kegiatan PKM ini menggunakan Inskcape, inkscape merupakan aplikasi berbasis opensource degan lisensi GPL yang mengijinkan siapa saja dapat menggunakan tanpa dipungut biaya sedikitpun. Meskipun tidak berbayar aplikasi ini menawarkan fungsional yang sama dengan aplikasi closed source(Adji, 2016). Aplikasi ini dapat berjalan di berbagai system operasi seperti windows, Linux bersert varianya. Dengan mengunakan aplikasi dalam pelatihan ini, diharapkan peserta dapat membuat hasil jadi dari berupa poster, dan template presentasi, dan lain-lain. Di masa pandemic, mahasiswa harus memiliki keterampilan supaya bisa bersaing di dunia kerja. 


\section{Metode}

Metode pelatihan yang dilaksanakan dalam pelatihan desain grafis berbasis vektor ini menggunakan pendekatan model klasik yaitu dimana bahan ajar telah ditetapkan sebelumnya berdasarkan kebutuhan teknik desain secara umum. Pelaksanaan pelatihan ini bekerjasama dengan sekelompok mahasiswa KKN dan dosen pembimbing dengan Fakultas $\mathrm{TI}$ Universitas Nurul Jadid selaku penyedia tempat untuk melaksanakan pelatihan ini. Pelatihan ini ditujukan untuk mahasiswa atau mahasiswi baik dalam lingkungan Universitas Nurul Jadid atupun dari kampus lain yang memiliki minat dalam desain grafis. Pelatihan dilaksanakan secara tatap muka atau luring, sehingga pada masa pandemi Covid-19 saat ini pelaksanaan pelatihan yang dilaksanakan di kampus Universitas Nurul Jadid pesertanya terbatas dengan tetap menerapkan protocol kesehatan. Pelatihan desain grafis memerlukan spesifikasi computer di atas standart agar proses desain tidak terhambat sehingga pelatihan dilakukan secara luring dengan memanfaatkan laboratorium fakultas TI. Peserta yang mengikuti pelatihan ini mendapatkan modul pembelajaran tentang Inkscape, materi, sertifikat serta apresiasi untuk 3 peserta terbaik dan 3 peserta yang beruntung berupa bantuan pulsa. Adapun tahapan dalam pelaksanaan pengabdian masyarakat dapat dilihat pada gambar (1) sebagi berikut:

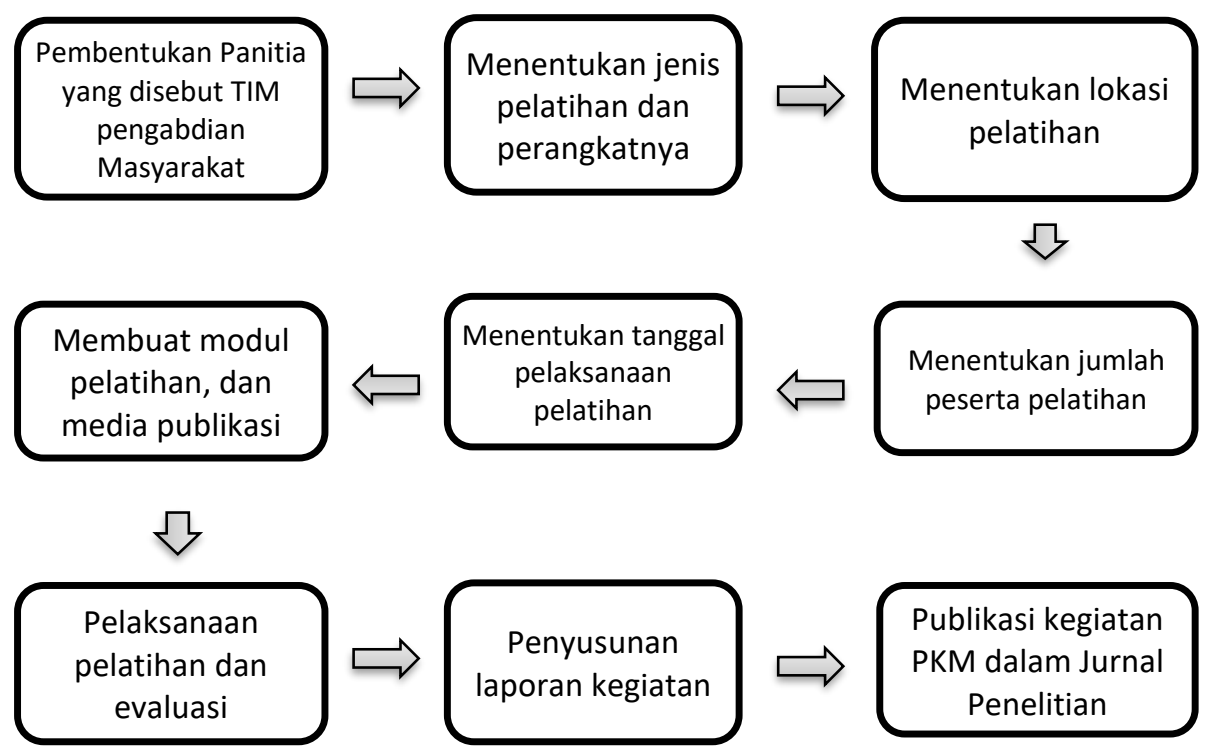

Gambar 1. Alur tahapan pelaksanaan pengabdian kepada masyarakat. 
Pada tahapan diatas dijeaskan secara rinci tahapan setiap proses pelaksanaan pengabdian kepada masyarakat dalam pelatihan desain grafis berbasis vektor sebagai berikut:

1. Pembentukan panitia yang disebut sebagai TIM Pengabdian Masyarakat yang memiliki 8 anggota terdiri dari 1 dosen fakulas TI prodi Rekayasa Perangkat Lunak yang berperan sebagai konseptor, Mentor dan fasilitator serta 7 Mahasiswa semester 4 dari jurusan Teknik Informatika.

2. TIM Pengabdian Masyarakat menentukan jenis pendampingan atau pelatihan pada mahasiswa yang memiliki minat bakat pada desain grafis untuk menambah wawasan dan penggunaan tool atau software desain grafis

3. TIM Pengabdian Masyarakat menentukan lokasi pelatihan dan disepakati bahwa pelatihan akan dilaksanakan dilingkungan kampus Nurul Jadid yaitu di ruangan laboratorium computer fakultas TI

4. TIM Menentukan metode palatihan yang tepat.

5. TIM Pengabdian Masyarakat menentukan jumlah peserta pelatihan dengan mempertimbangkan protocol kesehatan.

6. TIM Pengabdian Masyarakat menentukan tanggal pelaksanaan pelatihan dan menentukan pembagian tugas mulai dari : Pemesanan ruangan, form pendaftaran (google form), pembuatan flayer, pembutan banner, penyediaan konsumsi nasi kotak (dilarang makan bersama), Pembuatan modul pelatihan inkscape referensi dari website resme inkscape.com, Pembuatan sertifikat, Pembuatan soal atau quis secara online menggunakan quiziz.com untuk penentuan 3 peserta terbaik, pembuatan undian untuk 3 peserta yang beruntung menggunakan pickerwheel.com, dokumentasi, penyusunan laporan beserta publikasi jurnal.

Kegiatan ini merupakan langkah persiapan yang dijelaskan secara detail sebagai berikut:

a) TIM Pengabdian Masyarakat yang bertugas memastikan tempat atau ruangan laboratorium dapat digunakan pada tanggal yang ditetukan.

b) TIM Pengabdian Masyarakat membuat formulir pendaftaran yang dapat diakses secara online.

c) TIM Pengabdian Masyarakat memastika perangkat yang akan digunakan siap pakai termasuk memastikan software inkscape sudah terpasang.

d) TIM Pengabdian Masyarakat menyusun modul Inkscape dalam 3 bahasa (bahas ingris dan bhs indonesia).

e) TIM Pengabdian Masyarakat membuat materi dalam bentuk presentasi. 
f) TIM Pengabdian Masyarakat menyusun soal quis dengan memanfaatkan website penyedia layanan kuis online, kuis online yang dipilih adalah kuis yang dapat secara otomatis menentukan nilai terbaik secara real time berdasarkan akurasi dan kecepatan menjawab.

g) TIM Pengabdian Masyarakat membuat, menyusun dan mempublikasikan banner dan flayer melalui media social dsb

7. Pelaksanaan pelatihan desain grafis berbasis vektor mengunakan aplikasi berbasis open source. Pelatihan dilakukan dengan tatap muka atau luring dengan menerapkan ptotokol kesehatan. Tempat pelaksanaan di lingkungan Nurul Jadid Paiton Probolinggo. Teknik pelatihan menggunakan model klasik yaitu model pelatihan dengan bahan belajar desain grafis yang telah ditetapkan oleh program pelatihan/ belajar dengan kebutuhan peserta pelatihan dimana pemeteri telah memiliki modul atau hand out tentang materi pelatihan yang akan digunakan oleh peserta. Tujuan dari metode ini adalah mendekatkan kemampuan yang telah dimiliki oleh mahasiswa terkait desain grafis atapun peminat baru untuk mencoba mengenal hal baru. Pada akhir kegiatan dilakukan uji pemahaman terkait desain grafis secara online dan terpilih 3 peserta yang memiliki nilai terbaik. Mendokumentasikan segala bentuk kegiatan.

Langkah-langkah model klasik dapat dirinci sebagai berikut: 1). Identifikasikan kemampuan pada tujuan pelatihan; 2). Identifikasikan kemampuan peserta pelatihan; 3). Menetapkan kesenjangan kebutuhan pelatihan; 4). Mengembangkan program pelatihan; 5). Melaksanakan kegiatan pelatihan; 6). Penilaian.

8. Penyusunan laporan yang diakhiri dengan membuat dan menyusun laporan kegiatan dan disampaikan ke pada pimpinan Universitas sebagai bentuk pertanggungjawaban serta pemenuhan salah satu tugas tridarma perguruan tinggi.

9. Publikasi kegiatan pengabdian kepada masyarakat dalam bentuk jurnal ilmiah dengan harapan dapat memperbanyak referensi ilmiah tentang pelaksanaan pengabdian kepada masyarakat.

\section{Hasil}

Dari seluruh kegiatan yang dilaksanakan terkait pelatihan desain grafis berbasis vektor menggunakan aplikasi Inkscape ini dimulai dari pimbimbingan hingga pelaksanaan secara umum ada tiga tahapan, yang pertama tahap prakegiatan, yang kedua pelaksanaan kegiatan, dan yang ke tiga pasca kegiatan seperti pada gambar 1 di atas. Dari tiga tahapan dan detail rincian uraian proses kegiatan dapat dilihat pada timeline pada tabel 1. 
Tahapan yang pertama pra kegiatan meliputi:

1) Membentukan panitia kegiatan TIM Pengabdian Masyarakat yang memiliki 8 anggota terdiri dari 1 dosen fakulas TI prodi Rekayasa Perangkat Lunak yang berperan sebagai konseptor, mentor dan fasilitator serta 7 Mahasiswa semester 4 dari jurusan Teknik Informatika.

2) TIM Pengabdian Masyarakat menyusun dan membuat proposal pada kegiatan yang diajukan pada LP3M.

3) Software yang digunakan dalam pelatihan yaitu Inkscape. TIM memilih menggunakan inkscape sebagai alat untuk praktikum desain grafis dengan pertimbangan beberapa aspek yaitu: 1). fungsionalitas, Inskcape merupakan aplikasi desain grafik layaknya aplikasi desain lainya seperti Corel Draw, Adobe llustrator (Al) yang sudah sangat terkenal terlebih dahulu digunakan oleh desainer grafis. Ketiga aplikasi tersebut samasama powerfull untuk menghasilkan produk atau karya yang bagus dan professional; 2) aksesbilitas, Aplikasi Inkscape mudah didapatkan dengan langsung menunduh di website resmi www.inskcape.com secara gratis. Aplikasi Inkscape dapat digunakan diberbagai system operasi seperti Microsoft Windows, Mac OS, serta Linux dan variannnya. Tutorial sebagai penunjang atau pendamping pasca pelatihan tersedia cukup banyak diinternet dalam bentuk video maupun buku; 3). Legalitas, aplikasi Inskcape merupkan aplikasi open source (sumber kodenya teruka) dengan lisensi GPL (GNU General Public License) yang mengijikan siapa saja untuk mengngunakannya tanpa dipungut biaya sedikitpun. Inkscape dapat digunakan untuk membuat berbagai gambar vektor sesuai kebutuhan, misalnya untuk membuat gambar konten ilustrasi pada website, ikon untuk aplikasi pada smartphone, gambar kartun atau animasi, membuat garis sederhana, kaligrafi, logo, brosur, dan masih banyak lagi seperti halnya aplikasi desain grafis yang berbayar.

4) Tinjauan pustaka yang berkait dengan pelatihan desain grafis berbasis vector. Tinjauan pustaka ini dilakukan untuk menemukan data data dan teori sebagai acuan dalam penyusunan Materi pelatihan, buku panduan dalam proses pelatihan yang terintegrasi dengan Mendeley.

5) Lokasi pelatihan dan disepakati bahwa pelatihan akan dilaksanakan dilingkungan kampus Nurul Jadid yaitu di ruangan laboratorium computer fakultas $\mathrm{TI}$

6) Jumlah peserta pelatihan dengan mempertimbangkan protocol kesehatan sebanyak 15 peserta.

7) Pembagian tugas Pemesanan ruangan, form pendaftaran (google form), pembuatan flayer, pembutan banner, penyediaan konsumsi nasi kotak (dilarang makan bersama), Pembuatan modul pelatihan inkscape referensi dari website resme inkscape.com, Pembuatan sertifikat, 
Pembuatan soal atau quis secara online menggunakan quiziz.com untuk penentuan 3 peserta terbaik, pembuatan undian untuk 3 peserta yang beruntung menggunakan pickerwheel.com, dokumentasi, penyusunan laporan beserta publikasi jurnal.

Table 1. Pembagian tugas

\begin{tabular}{clc}
\hline No & \multicolumn{1}{c}{ Kegiatan } & Pelaksana \\
\hline 1 & Menyusun Proposal & Muhammad Miftahul U \\
\hline 2 & Melakukan prerijinan tempat & Muhammad Irfan \\
\hline 3 & Membuat form pendaftaran online & Abdul wafi \\
\hline 4 & Membuat flayer dan publikasi & Muhammad Nabil M \\
\hline 5 & Observasi lokasi & Muhammad Irfan \\
\hline 6 & Pengecekan/Instalasi software inkscape & Muhammad Irfan \\
\hline 7 & Membuat banner dan mencetak & Abdullah \\
\hline 8 & Mencari literatur dan membuat materi & Eko Purnomo \\
\hline 9 & slide presentasi & Menyusun modul \\
\hline 10 & Transalate modul & A Dimas Aul M \\
\hline 11 & Membuat kuis dan undian onlie & Pemateri \\
\hline 12 & Desain sertifikat & Abdullah \\
\hline 13 & Dokumentasi & Abdul Hafid \\
\hline 14 & Menyediakan konsumsi & Miftahul Ulum \\
\hline 15 & Menyusun aporan & Muhammad Irfan \\
\hline
\end{tabular}

8) TIM Pengabdian Masyarakat yang bertugas mendapat persetujuan penggunaan tempat atau ruangan laboratorium yaitu di Gedung D, Ruang Lab 4 Laboratorium komputer dengan kapasitas 30 komputer dan ruang Dosen putra dengan kapasitas 10 komputer sehingga dipilih ruangan yang lebih banyak menampung peserta.

9) Perangkat yang akan digunakan pada lab computer telah memiliki spesifikasi yang cukup. TIM melakukan instalasi software inkscape.

10) Menyusun modul Inkscape dalam 3 bahasa (Bahasa Inggris dan Bahasa Indonesia) materi didapatkan dari berbagai buku latihan inkscape yang diperoleh dari Jurnal, Google Book, dan website resmi inkscape.

11) TIM Pengabdian Masyarakat membuat materi dalam bentuk presentasi. Materi yang disampaikan merupakan representasi dari modul yang berisikan pengenalan desain, jenis gambar, jenis software, pemilihan warna, membuat objek, menggunakan path, membuat teks pada logo, 
membuat poster, membuat template kotak kemasa produk, membuat barcode/qrcode. DII.

12) TIM Pengabdian Masyarakat menyusun soal quis pada situs penyedia kuis secara gatis: Membuat akun di quiziz.com dan upload qius.

13) TIM Pengabdian Masyarakat membuat dan menyebarkan media informasi seperti banner dan flayer melalui media social dan sebagainya.

14) TIM Pengabdian Masyarakat memastikan jumlah peserta yang sudah mendaftar tidak lebih dari 15 peserta

Tahap ke dua pelaksanaan kegiatan meliputi

1) Pelaksanaan pelatihan desain grafis berbasis vektor mengunakan Inkscape dilaksanakan pada hari sabtu tanggal 19 Juni 2020 pukul 09.00 s.d 15.00 WIB.

2) Jumlah Peserta sebanyak 15 peserta baik dari Universitas Nurul Jadid dan dari luar Universitas Nurul Jadid.

3) Tempat pelaksanaan di Gedung D, Ruang Lab 5 Laboratorium komputer.

4) Teknik pelatihan menggunakan model dimana materi atau bahan ajar bersumber pada standar pembelajaran desian grafis pada umumnya. Identifikasi kesenjangan dengan kebutuhan diidentifikasi saat pelatihan berlangsung. Model ini bertujuan untuk mendekatkan kemampuan yang telah dimiliki dengan kemampuan yang akan dipelajari, sehingga peserta pelatihan tidak akan memperoleh kesenjangan dan kesulitan dalam mempelajari materi yang sudah diberikan. Tahap awal pelaksanaan sebelum pelatihan diberikan peserta diberikan pertanyaan seputar desain grafik guna mendapatkan informasi sejauh mana pemahaman peserta terkait desain grafis beserta aplikasi yang pernah digunakan. Selanjutnya pemberian materi tentang pengantar awal tentang desain grafis, bagaimana meningkatkan kualitas desain grafis, bagaimana memahami dan menggunakan tool-tool dan fasilitas dasar pada aplikasi Inkscape, pemilihan kombinasi warna dan keseimbangan, materi terkait jenis gambar, macam software yang dapat digunakan, dan risiko pelanggaran hokum terhadap penggunaan aplikasi bajakan sesuai Undang-Undang No 11 tahun 2008 Tetang Internet dan Transaksi Elektronik (ITE).

5) Pemateri memberikan contoh kemudian diikuti oleh peserta. Pemateri dibantu oleh TIM sebagai pendamping peserta jika ada yang mengalami kesulitas. Modul pelatihan diberikan kepada peserta sebagai bahan ajar dan pendamping untuk praktikum setelah pelatihan usai. Pemateri mencontohkan didepan kelas tentang tool yang digunakan dalam aplikasi inkscape seperti pada gambar 2 . 

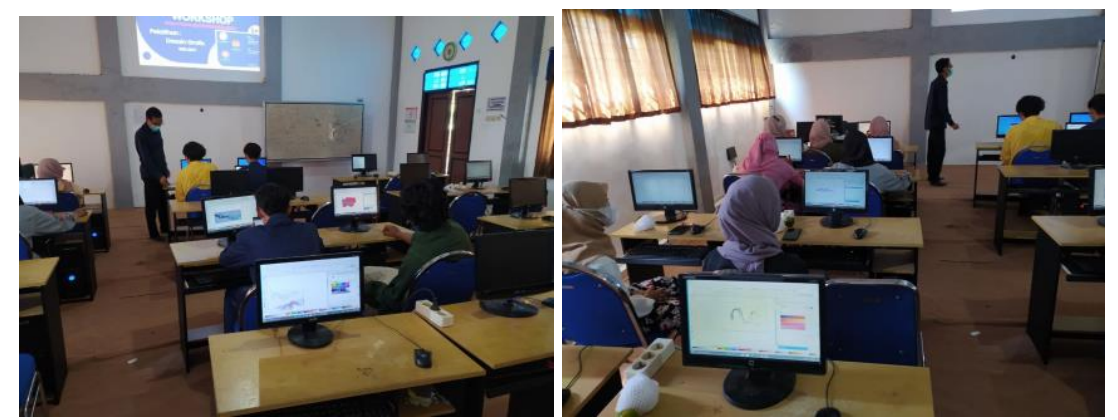

Gambar 2. Penyampaian materi dan penarahan

Peserta melakukan percobaan menggunakan aplikasi Inkskape melalui komputer yang sudah disediakan. Setelah peserta memahami menggunakan fasilitas dasar dari aplikasi pesereta diberikan tantangan untuk menduplikasi gambar jadi yaitu Praktikum objek dasar dan desain logo (gambar 3), menggambar dengan menu interpolasi (gambar 4), membuat desain kotak kemasan produk (gambar 5), membuat template poster penelitian (gambar 7), dan lain sebagainya.

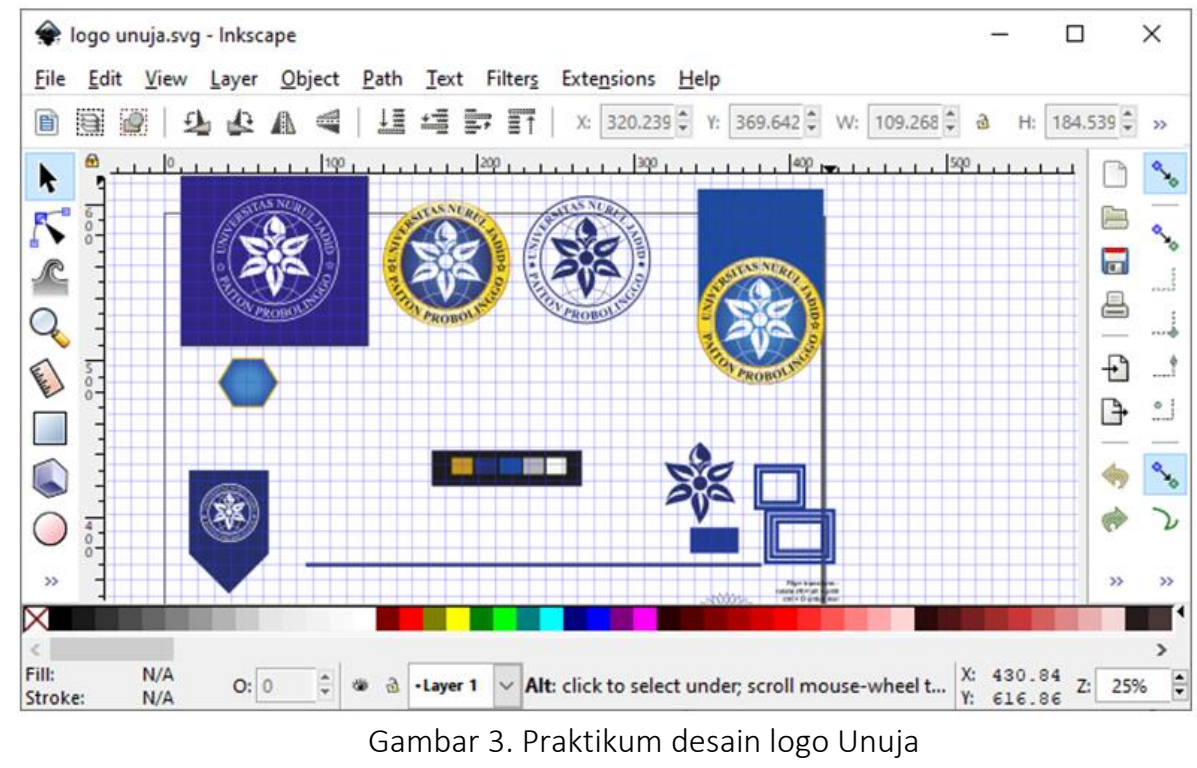




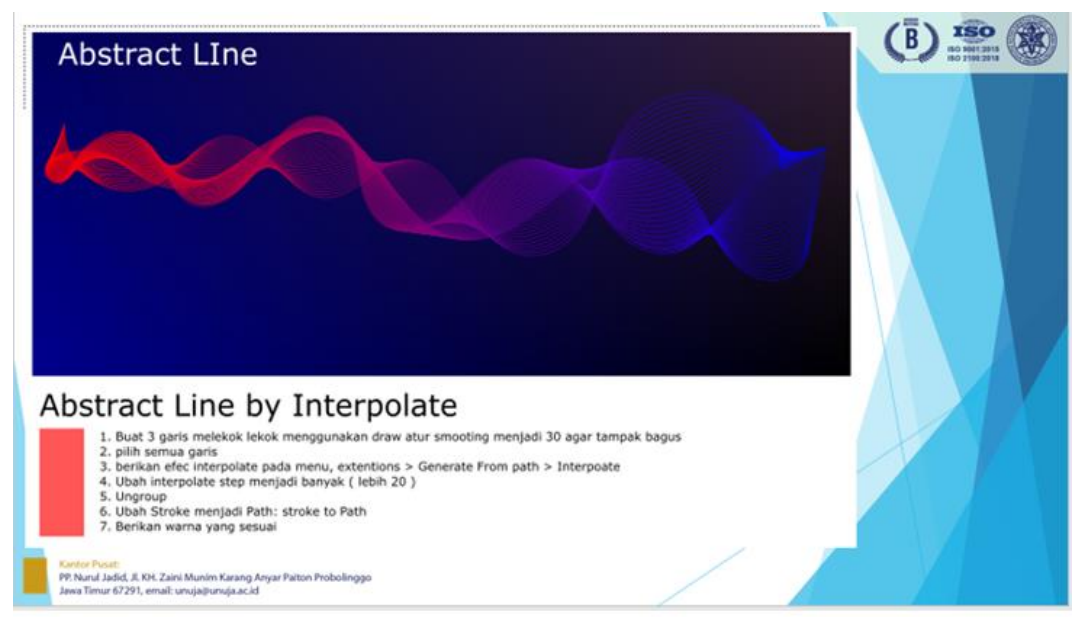

Gambar 4. Menggambar line abstrak dengan interpolate

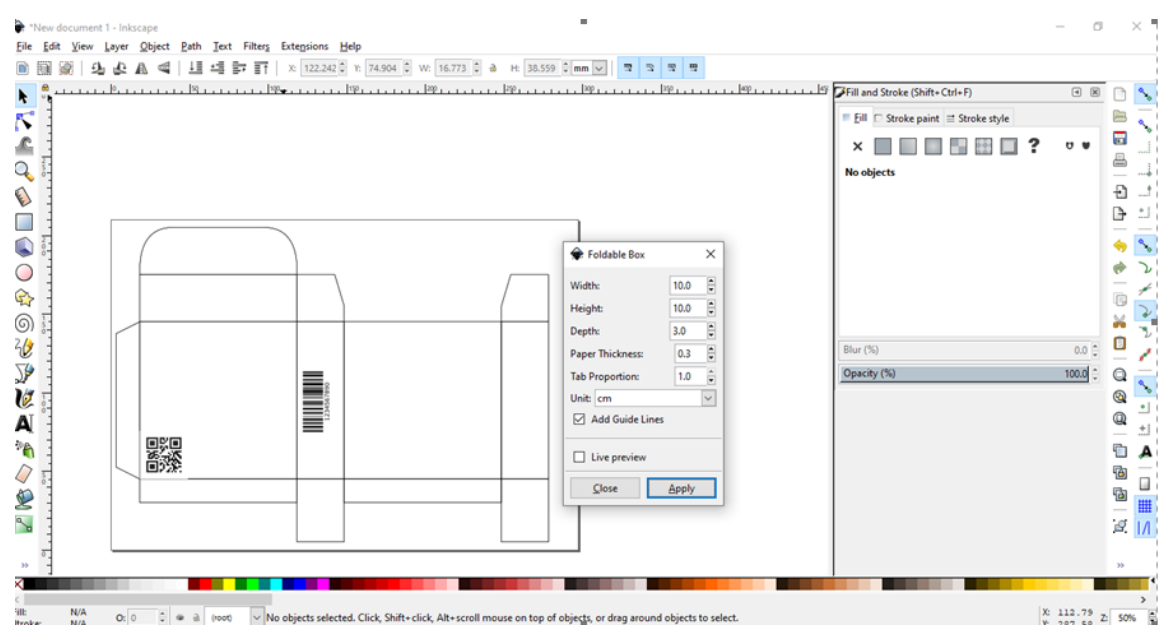

Gambar 5 Membuat kotak kemasan produk

Penggunaan dan penggabungan warna diberikan beberapa perpaduan contoh warna yang dapat diaplikasikan dengan memanfaatkan website yang telah menyediakan kombinasi warna yang serasi. 


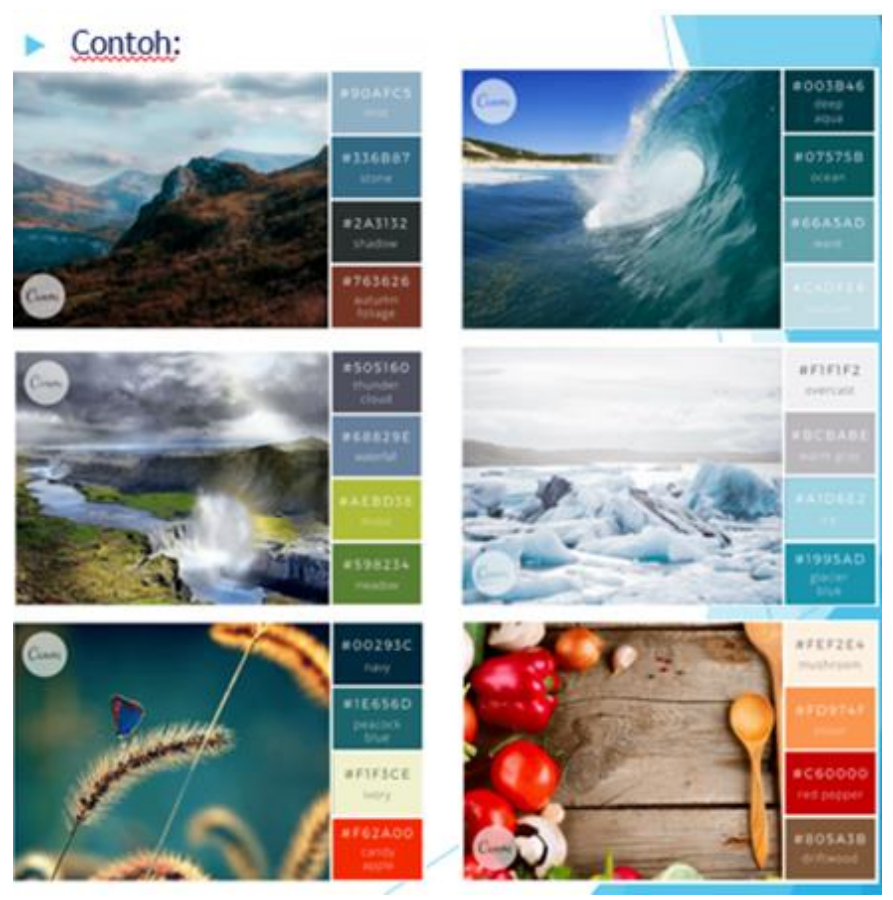

Gambar 6 Contoh melakukan Pemilihan warna dari media lain

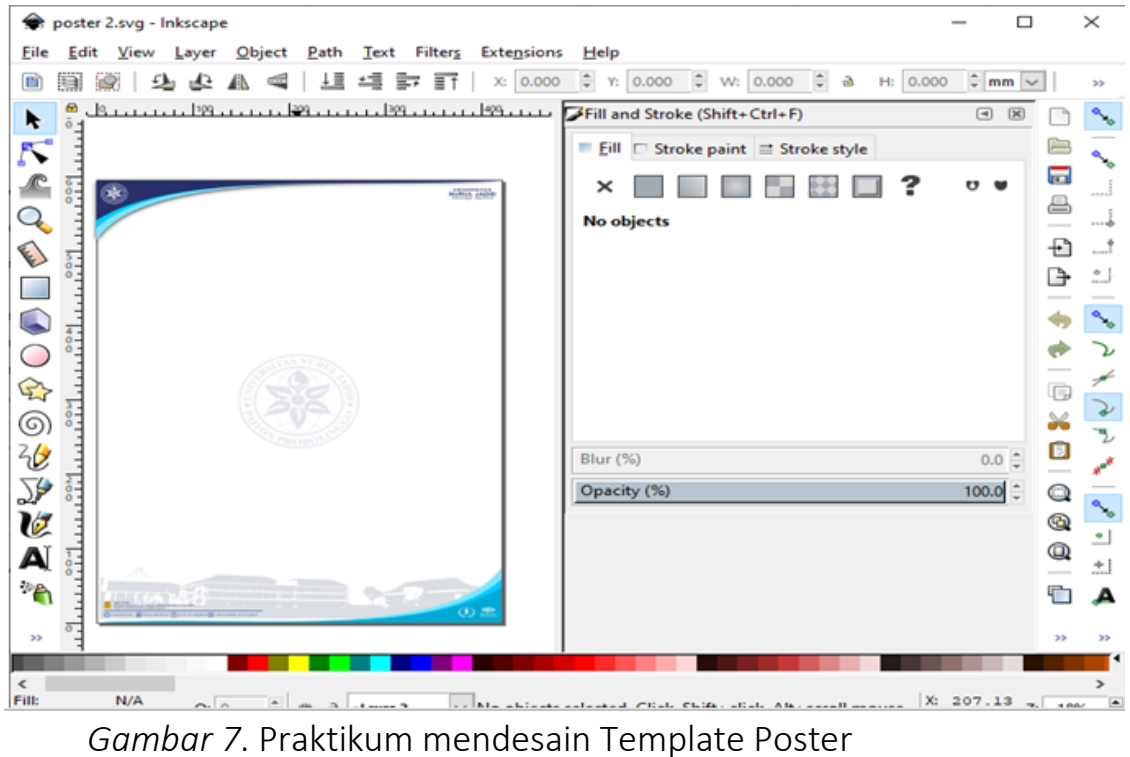

Pemateri dibantu oleh TIM Pengabdian Masyarakat untuk mendampingi peserta yang merasa kesulitan. Istirahat diberikan 10 menit untuk memulihkan fokus peserta dilakukan permainan tebak keberuntungan dengan memanfaatkan situs pickerwheel.com. 
Pada akhir kegiatan dilakukan evaluasi pemahaman terkait materi yang diberikan secara online melalui situs www.quiziz.com. Dari hasil evaluasi terpilih 3 peserta yang memiliki nilai terbaik. Kegiatan ini dilakukan dengan tujuan untuk mengetahui perkembangan SDM para peserta setelah menerima pelatihan. Tingkat pemahaman para peserta terlihat pada sesi ini. Peserta dengan nilai tertinggi diberikan apresiasi berupa bantuan pulsa.

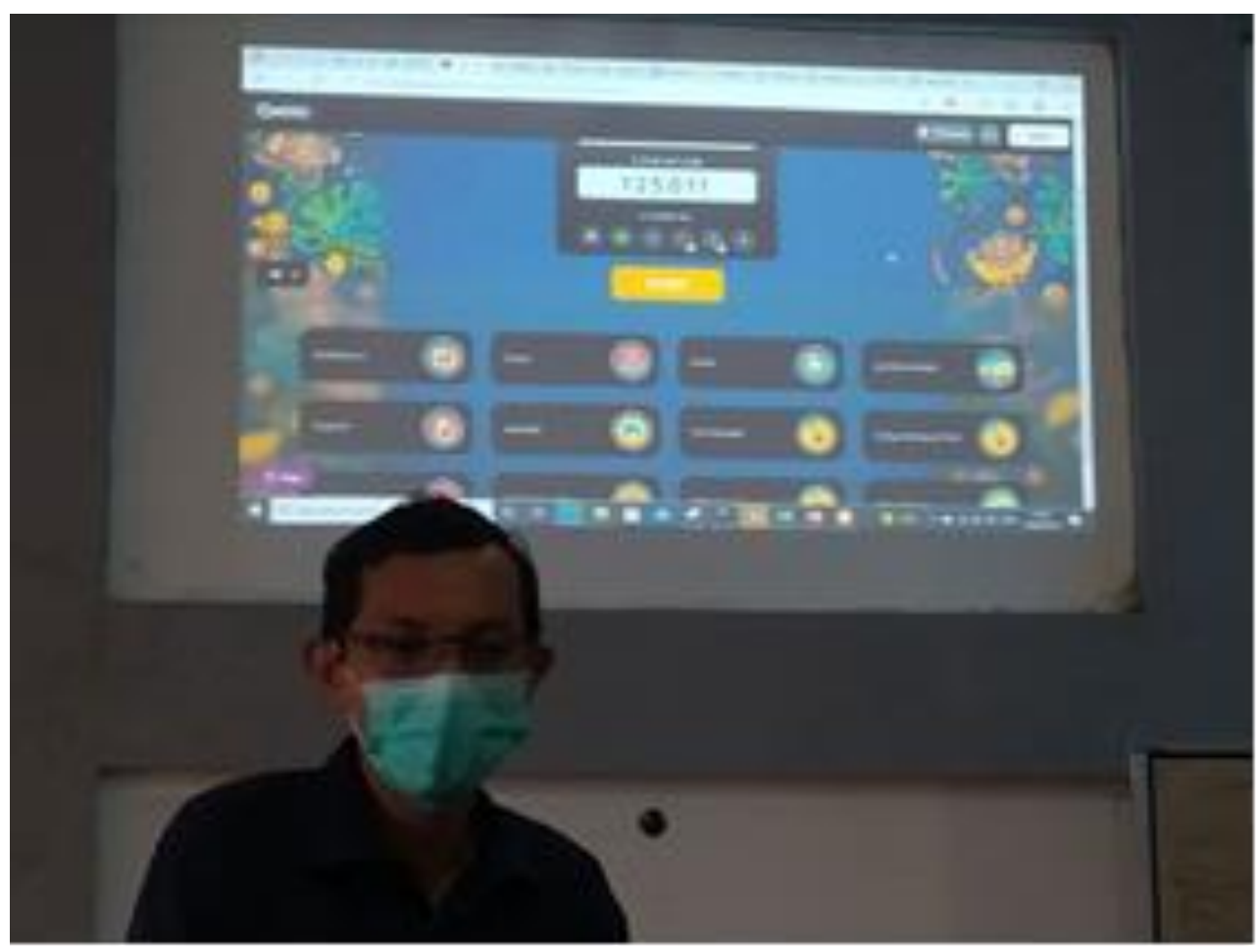

Gambar 8. Kuis uji pemahaman pesereta

Selanjutnya TIM yang bertugas melakukan dokumentasi segala bentuk kegiatan seperti, Proposal, kwitansi pembayaran, materi \& modul, daftar hadir, foto kegiatan dan laporan. Sharing dokumentasi menggunakan aplikasi Telegram sehingga semua angota dapat melaporkan dan menerima informasi dengan tepat waktu.

Tahap Akhit yaitu paska kegiatan pelaksanaan meliputi:

1) Penyusunan laporan yang diakhiri dengan membuat dan menyusun laporan kegiatan dan disampaikan ke pada pimpinan Universitas sebagai bentuk pertanggungjawaban serta pemenuhan salah satu tugas tridarma perguruan tinggi. 
2) Publikasi Jurnal IImiah pada Jurnal IImiah GUYUB: Journal of Community Engagement. Kegiatan pengabdian masyarakat ini menggunakan pendekatan ilmiah, dimana Publikasi dijurnal ilmiah dengan harapan dapat memperbanyak referensi ilmiah tentang pelaksanaan pengabdian kepada masyarakat.

\section{Pembahasan}

Pengabdian kepada masyarakat dalam bentuk pelatihan desain grafis berbasis vektor dengan menggunakan software inkscap dilaksanakan pada hari sabtu tanggal 19 Juni 2021 di lingkungan Nurul Jadid. Terdapat 4 tahapan mulai dari perencanaan hingga menyusun laporan. Tahap pertama yaitu perencanaan, pada tahap ini dibentuk TIM Pengabdian kepada masyarakat dari kelompok Kuliah Kerja Nyata (KKN) yang terdidi dari satu pembimbing dan delapan anggota, koordinasi antar anggota pada masa pendemi sedikit mengalami kendala komunikasi. Komunikasi dilakukan secara daring dengan melalui video conference, dalam hal ini menjadi tidak efektif dikarenakan signal jaringan yang ada pada beberapa anggota tidak mendukung. Meskipun demikian koordinasi tetap berjalan sesuai timeline dengan memanfaatkan media social (Group telegram). Pemanfaatan aplikasi telegram menjadi hal yang sangat menunjang koordinasi, karena salah satu manfaat yang dapat digunakan yaitu aplikasi telegram dapat menyimpan file pada server, sehingga segala bentuk dokumentasi yang disampaikan oleh anggota tersampaikan dan tersimpan dengan baik. Aplikasi telegram mengedepankan fitur-fitur yang sangat dibutuhkan oleh warga digital. Tugas tugas yang diberikan dapat dilaksanakan dengan baik. Pembagian tugas dilakukan berdasarkan kesanggupan yang berdasar pada kemampuan masing masing anggota.

Tahap pertama pra kegiatan yaitu menitiberatkan pada pentingnya perencanaan dan eksekusi. Persiapan mulai dari kepastian tempat, kesiapan perangakat computer, kesiapan media publikasi informasi, kesiapan modul, dan lain-lain. Keberhasilan dari sebuah kegiatan tidak lepas dari kerjasama. Pembagian tugas yang menjadi tanggung jawab anggota tidak semua dapat dikerjakan dengan sempurna jika mengandalkan kerja secara individual. Kerja bersama, berbagi pengalaman, dan saling melengkapi menambah pengalaman anggota lebih luas, sehingga tugas dapat terselesaikan dengan baik. Pada tahap persiapan peran monitoring menjadi hal yang perlu 
dilakukan lebih intens untuk memastikan kegiatan persiapan dapat terselesaikan secara tepat waktu. Monitoring dilakukan melalui group telegram yaitu dengan melaporkan setiap ada kendala atau hasil dari masing masing anggota pada group sehingga laporan penyelesaian atauun kendala dari masing-masing anggota dapat tersampaikan ke semua anggota.

Tahap ke dua yaitu pelaksanaan, pada tahap ini dilakukan pelatihan dengan model pelatihan klasik dimana materi atau bahan ajar bersumber pada standar pembelajaran desian grafis. Model klasik merupakan bagian dari model pelatihan dan pengembangan keterampilan berdasarkan minat atau kebutuhan peserta atau dikenal dengan TNA (training Needs Analisys) Alison Rossett and Joseph W. Arwady, 1987 dalam jurnal.(Simamora, n.d.).

Pada awal pelatihan telah diberikan beberapa pertanyaan atau pre-test untuk mengetahui tingkat pemahaman peserta terkait desain grafis. Hasil dari identifikasi pemahaman peserta adalah sebagai berikut:

a) Peserta mengatahui tentang desain grafis

b) Peserta pernah melakukan editing gambar raster seperti foto

c) Aplikasi yang pernah digunakan Photoshop dan Corel Draw

d) Peserta belum mengetahui perbedaan gambar raster dan vektor

e) Peserta belum pernah menggunakan aplikasi inkscape

f) Peserta selama ini menggunakan aplikasi Close Source dengan tanpa memenuhi kewajiban sebagai pengguna aplikasi berbayar.

g) Peserta masih mengabaikan risiko dari penggunaan aplikasi berbayar secara tidak sah.

Berdasarkan hasil identifikasi tingkat pemahaman peserta diberikan materi terkait jenis-jenis gambar, macam software yang dapat digunakan untuk mengolah gambar vektor seperti (Adobe Ilustrator, Corel Draw dan Inkscape), risiko menggunakan aplikasi illegal atau bajakan, serta mengenalkan penggunaan aplikasi Inkscape. Praktikum mendesain berbagai objek kemudian diikuti oleh peserta, Pemateri dibantu oleh TIM sebagai pendamping peserta jika ada yang mengalami kesulitan.

Jendela utama inkscape terdiri dari beberapa menu di antaranya; Name File, Menu Bar, Command Bar, Control Bar, Canvas, Toolbox, Color Palette, Status Bar, dan lain-lain. 


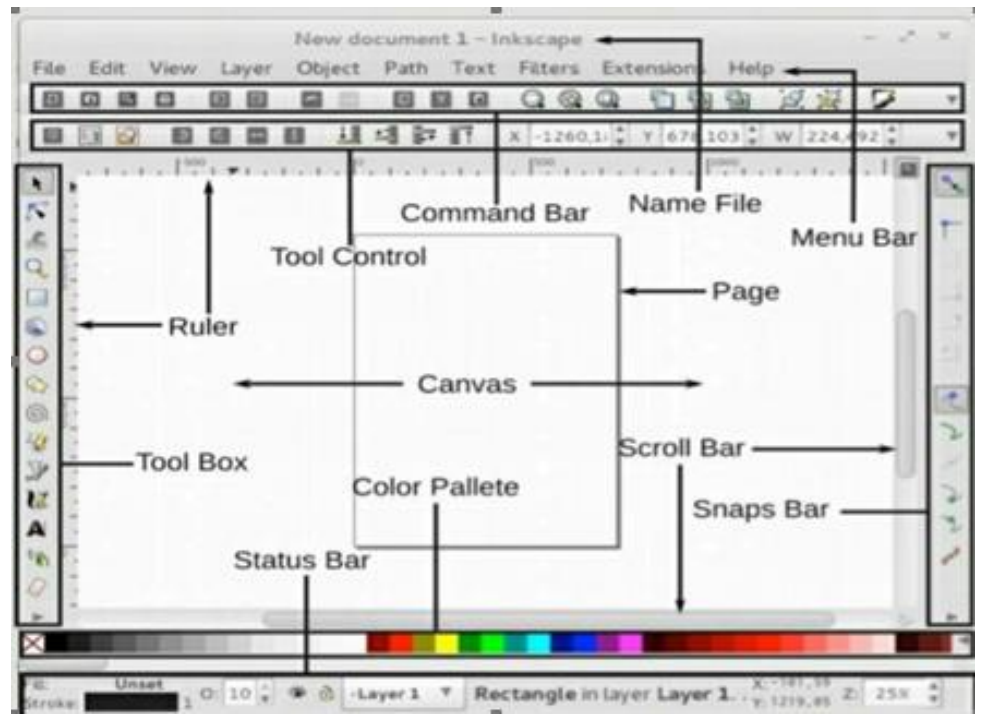

Gambar 9. Menu pada aplikasi Inkscape

Menu yang ada di aplikasi inkscape tampak lebih sederhana dibandingkan dengan aplikasi desain lainnya. Namun tetap memungkinkan seorang desain grafis menghasilkan karya karya yang tidak kalah dengan menggunakan aplikasi berbayar (propiatery) seperti karya para juara yaitu Karya Bayu Rizaldhan dan Fauzan Sukri yang diselenggarakan oleh Inkscape.

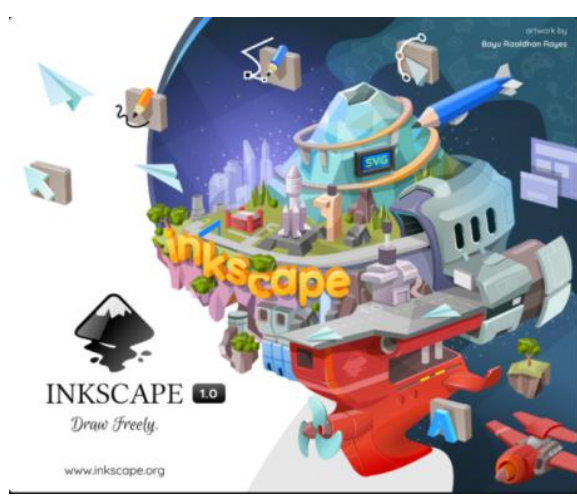

Karya Bayu Rizaldhan

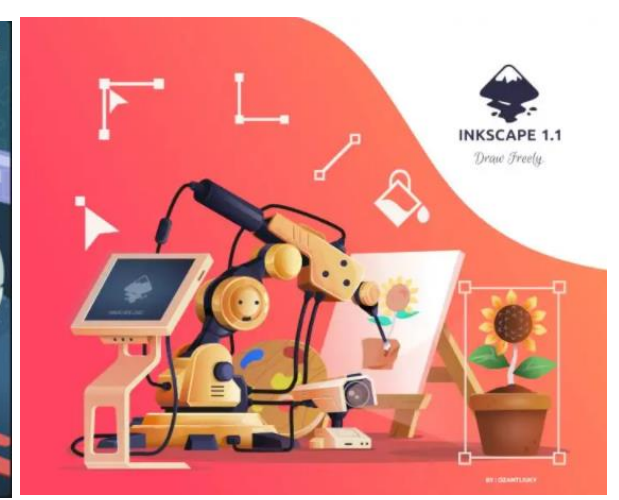

Karya Fauzan Sukri

Gambar 10. Karya Bayu Rizaldhan (kiri), Karya Fuzan Sukri (kanan)

Pengenalan aplikasi baru bagi peserta dapat diterima dengan cara menunjukan hasil karya para desainer yang menggunakan Inkscape seperti pada gambar 10. Hal ini menjadi salah satu pertimbangan akan penggunaan terhadap aplikasi berbayar (propiatery) dari hasil bajakan (crack) karena terdapat risiko pelangaran hukum pada Undang-undang No 19 Tahun 2002 Tentang Hak Cipta, dan Undang-Undang No 11 tahun 2008 Tetang Internet dan Transaksi Elektronik (ITE).(Persetujuan Bersama, n.d.) 
Sedikit pemahaman tentang aplikasi alternative yang memiliki fungsi tidak jauh beda dari aplikasi berbayar dan adanya risiko pelanggaran hukum membuat peserta sangat antusias untuk memcoba aplikasi Inkscape. Pengenalan menu fasilitas dasar aplikasi inkscape membuat peserta tertarik namun juga terlihat beberapa peserta yang baru mengenal desain sedikit kesulitasn memahaminya, hal itu dapat dilihat dari ada beberapa peserta yang meminta pengarahan kepada pemateri. Kegiatan menggambar oleh peserta dapat dilakukan dengan lebih mudah setelah diberikan pendampingan dan arahan oleh TIM. Setelah dapat menggunakan fasilitas dasar pada aplikasi peserta diberikan tantangan untuk menduplikasi contoh desian jadi. Model ini diberikan mengasah keterampilan, mengatasi kesulitan untuk mencapai tujuan yang diharapkan. Hal ini selaras dengan seperti yang disampaikan Yohan (2019) dalam penelitihan Agustin Husnul Khotimah "Problem-based learning (PBL) is a way of composing and teaching a learning process using the issue as a stimulus/arousal and the focus is more on the activity of students".(Khotimah et al., 2019). Dua belas peserta dari 15 peserta mampu menghasilkan karya sesuai tantangan. Desain dapat dibuat secara cepat dengan kreatifits dan pemahaman memanfaatkan tool yang tersedia secara instan pada aplikasi inkscape. Hal ini untuk menimbulkan persepsi bahwa desain grafis tidak sulit dan tidak pelru menggunakan aplikasi bajakan.

Selain bagaimana mendesain suatu karya hasil pemikiran pribadi perserta diberikan pengalaman untuk dapat menggunakan desain atau mengubah gambar jadi yang tersedia di website. Hal ini untuk memberikan informasi bahwa hasil karya dapat dipublikasikan dan bahkan dapat menjadi nilai tambah.

Pada akhir kegiatan pelatihan dilakukan evaluasi hasil pelatihan melalui post test. Hasil pos test mencerminkan tingkat pemahaman dan tingkat keberhasilan dalam pelaksanaan pelatihan. Akurasi hasil tes tertinggi $89 \%$ dan akurasi terendah adalah 33\%. 


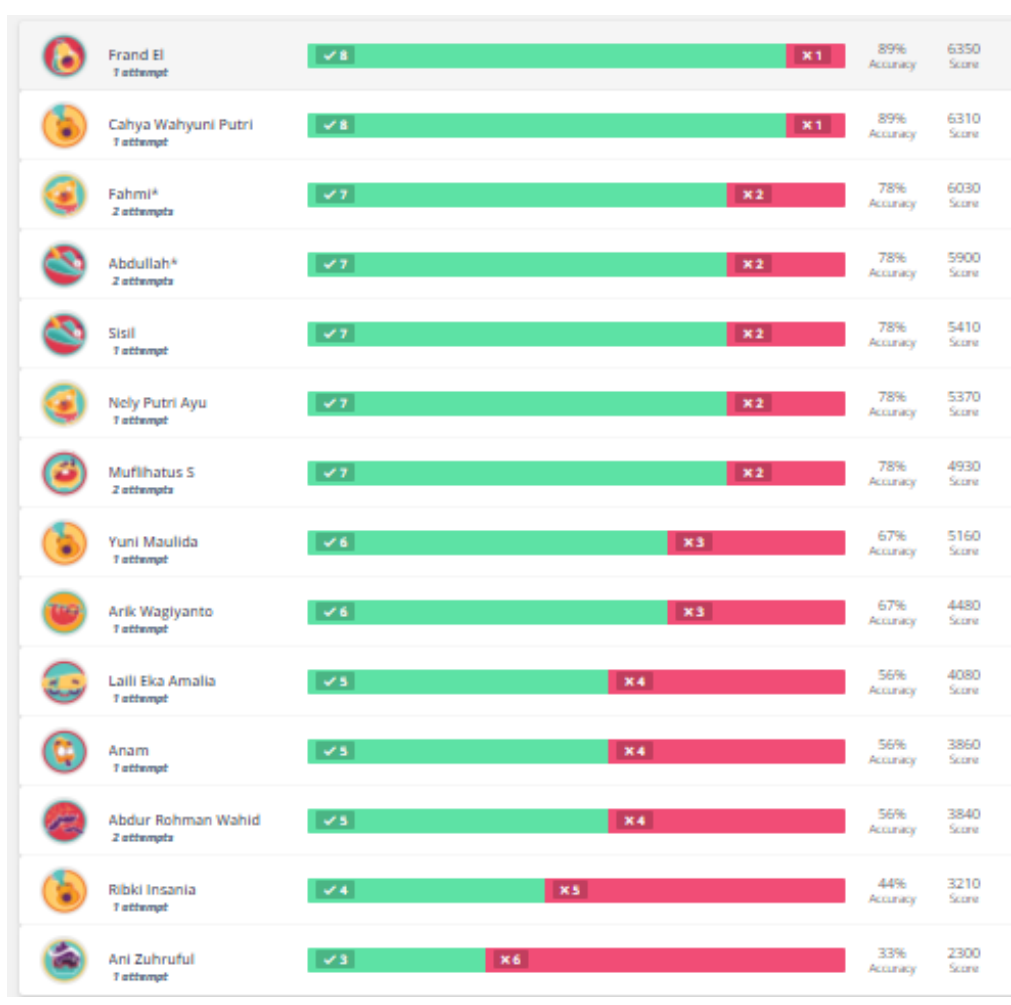

Gambar 11. Hasil penilaian pelatihan

Apresiasi diberikan kepada 3 peserta terbaik yaitu berdasarkan akurasi dan tingkat kecepatan dalam menyelesaikan. Workshop ini mendapatkan antusiasme dan semangat yang cukup besar dari para peserta. Interaksi dua arah berjalan dengan baik dan diskusi terhadap materi yang diberikan juga berjalan lancar. Pemateri kemudian memonitor keseluruhan pelatihan dan membantu penyelesaian masalah dan kendala yang di hadapi oleh peserta. Walaupun hasil dari praktikum bersama belum maksimal karena keterbatasan waktu pelatihan, namun para peserta sudah mampu menggunakan aplikasi inkskape dengan baik dan mampu mendesain sesuai materi yang diberikan dalam pelatihan.

Melalui kegiatan pelatihan desain grafis ini di dapat menambah peningkatan pengetahuan tentang teknis desain grafis, macam-macam aplikasi desain grafis, risiko pengunaan aplikasi bajakan dan alternatifnya serta keterampilan desain grafis. Berkaitan dengan hal ini maka diharapkan dapat menjadi motivasi mahasiswa bagi yang mendalami bidang desain grafis agar dapat bersaing di dunia kerja. 


\section{Kesimpulan}

Pelaksanaan pengabdian kepada masyarakat dengan tema Pelatihan desain grafis untuk memberikan tambahan pengetahuan dan keterampilan berjalan dengan baik, tertib dan lancar sesuai apa yang direncanakan sebelumnya. Peserta kegiatan pelatihan ini sangat antusias mengikuti pelatihan desain grafis. Dari keseluruhan pelaksanaan pelatihan menunjukan hasil yang positif meningkatkan keterampilan wawasan dan motivasi belajar mahasiswa terhadap bidang desain grafis. Serta pengetahuan tentang aplikasi desain grafis open source yaitu Inkscape juga dapat menghasilkan karya yang bagus sama halnya aplikasi desain grafis berbayar (propiatery) seperti Corel Draw dan Adobe Ilustrator yang dapat digunakan sebagai aplikasi alternative apabila ada keterbatasan dana.

\section{Pengakuan}

Ucapan terima kasih disampaikan kepada pembina PKM atas arahan dan pembinaanya selama proses kegiatan workshop berlangsung. Demikian pula ucapan terima kasih disampaikan kepada pihak Fakultas Teknik Universitas Nurul Jadid yang telah memberi fasilitas untuk kegiatan workshop hingga selesai.

\section{Referensi}

Adji, T. S. (2016). Inkscape: 23 Tutorial Menggambar. https://play.google.com/books/reader?id=9UUPBQAAQBAJ\&pg=GBS.P A2\&hl=id\&printsec $=$ frontcover

Antonius, S., \& Sama, H. (2020). STUDI KOMPARASI BITMAP DAN VEKTOR TERHADAP KUALITAS DIGITAL ART: CASE STUDY DEVIANTART NABHAN DAN PIXELJEFF1995 / Conference on Business, Social Sciences and Innovation Technology. Conference on Business, Social Sciences and Innovation

Technology.

https://journal.uib.ac.id/index.php/cbssit/article/view/1467

Iswandi, H. (2018). Peran dan Pengaruh Tampilan Desain pada Periklanan. Seni Desain Dan Budaya, volume 3(Issue 3), 100-109. www.palembangpos.com. 
Khotimah, A. H., Kuswandi, D., \& Sulthoni, S. (2019). PENGARUH MODEL PROBLEM BASED LEARNING TERHADAP HASIL BELAJAR PKN SISWA. Jurnal Kajian Teknologi Pendidikan, 2(2), 158-165. http://journal2.um.ac.id/index.php/jktp/article/view/8112

Persetujuan Bersama, D. (n.d.). DEWAN PERWAKILAN RAKYAT REPUBLIK INDONESIA dan PRESIDEN REPUBLIK INDONESIA.

Piliang, Y. A. (2019). SENI, DESAIN DAN KEBUDAYAAN DALAM SPIRIT REVOLUSI INDUSTRI 4.0. In Prosiding Seminar Nasional Desain dan Arsitektur (SENADA)

(Vol.

2).

https://eprosiding.idbbali.ac.id/index.php/senada/article/view/247

Pramesti, I. A., \& Irwansyah. (2021). Faktor yang Memengaruhi Minat dan Cara Membaca Masyarakat Indonesia di Era Digital, serta Dampaknya Pada Bisnis Media Cetak. Titian: Jurnal Ilmu Humaniora, 5(1), 117-131. https://online-journal.unja.ac.id/titian/article/view/10695

Riyanto, G. P. (2021). Jumlah Pengguna Internet Indonesia 2021 Tembus 202 Juta. https://tekno.kompas.com/read/2021/02/23/16100057/jumlahpengguna-internet-indonesia-2021-tembus-202-juta

Simamora, L. (n.d.). 94423228-Model-Model-Pelatihan.

Zubaedah Hanum. (2021). Kemenkominfo: 89\% Penduduk Indonesia Gunakan Smartphone.

https://mediaindonesia.com/humaniora/389057/kemenkominfo-89penduduk-indonesia-gunakan-smartphone 